\title{
Determinants of Regional Distribution of FDI Inflows across China's Four Regions
}

\author{
Kelly Liu ${ }^{1}$, Kevin Daly ${ }^{1} \&$ Maria Estela Varua ${ }^{1}$ \\ ${ }^{1}$ School of Business, University of Western Sydney, Australia \\ Correspondence: Assoc. Prof. Kevin Daly, School of Business, University of Western Sydney, Australia. E-mail: \\ k.daly@uws.edu.au
}

Received: October 2, 2012

Accepted: November 5, 2012

Online Published: November 14, 2012

doi:10.5539/ibr.v5n12p119

URL: http://dx.doi.org/10.5539/ibr.v5n12p119

\begin{abstract}
This paper performs an empirical assessment of China's inward FDI by analysing the relative importance of the potential determinants of FDI inflows across the four regions of China for the period 2001-2009. The determinants examined are: Market size, labour cost, labour quality, physical infrastructure development, telecommunication, degree of economic openness and government incentives to attract FDI. Our paper employs a multiple regression model for each region and then compares the results across four regions. The results indicate a mixed picture, for example we find that market size holds priority for FDI inflows into coastal region and northeast regions while the degree of openness is the most important determinant for FDI inflows in central region. The labour quality has no effect in central region but has a positive impact on FDI inflows into coastal and northeast regions. These results have important implications for China's regional policy makers as they can help them identify the kinds of industries which respond to specific drivers and identify regional social economic characteristics which are more attractive to particular FDI inflows.
\end{abstract}

Keywords: China, manufacturing, FDI, regional, determinants

\section{Introduction}

Since China opened its economy to foreign investors in 1979, the Foreign Direct Investment (FDI) inflows into China have increased dramatically especially after China joined the World Trade Organisation (WTO) in 2001. By the end of 2010, the cumulative FDI inflows to China reached USD 1047 billion. However, the geographical distribution of FDI inflows in China indicates a great disparity across China's four geographic regions. FDI inflows to China were overwhelmingly concentrated in the coastal region, which accounted for more than 75 per cent of total utilised FDI. Several studies indicate that FDI inflows play an increasingly important role in regional economic development (Kang \& Lee, 2007). In order to accelerate economic development in underdeveloped inland regions, China's central government has favoured a policy of encouraging foreign investment in those regions. In an attempt to prioritise the importance of factors driving FDI inflows, this paper investigates the regional determinants of FDI inflows by analysing the relative importance of potential determinants of FDI inflows across four regions in China. The most recent regional classification adopted by the National Development and Reform Commission (NDRC) which is based on regional geographical characteristics, industrial development and national planning (Note 1) is also used in this study. Accordingly, all provinces in China are grouped into four regions, namely, the coastal region, northeast region, central region and western region (Note 2). The coastal region is located in the southeast of China and represents 9.5 per cent of the national land area; the northeast region represents 8.2 per cent of national land area while the western region has the largest share of national land area accounting for appropriately 71.5 per cent of China's land mass while the central region accounts for 10.7 per cent of the total national land area.

Figure 1 presents the FDI inflows into China's four Regions over the period 1987 to 2009 and three sub-periods 1987 to 1991, 1992 to 2001 and 2001 to 2009 (Note 3). Over the first sub-period (1987-1991), total FDI inflows to China was at a low level, and overwhelmingly concentrated in the coastal region, with the coastal region attracting 85 per cent of cumulative FDI inflows to China, while northeast, central and western regions received 6.7 per cent, 3.0 per cent and 5.3 per cent, respectively. The Chinese government gradually opened more areas to foreign investment and continually implemented new policies and regulations to encourage FDI inflows especially after former leader Deng Xiaoping calls for deeper, faster and wider economic reform and 
liberalisation in 1992. Subsequently FDI inflows increased dramatically and gradually spread from the initial concentration areas to other regions. The share of cumulative FDI inflows to the coastal region in the 1992 2001 period decreased to 81 per cent from 85 per cent in previous era, while the share going to central region increased from 3.0 per cent to 7.2 per cent. Figure 1 indicates a decreasing trend of FDI inflows across all four regions in the period 1998-2000. This trend was due to the negative impact of the Asian financial crisis.

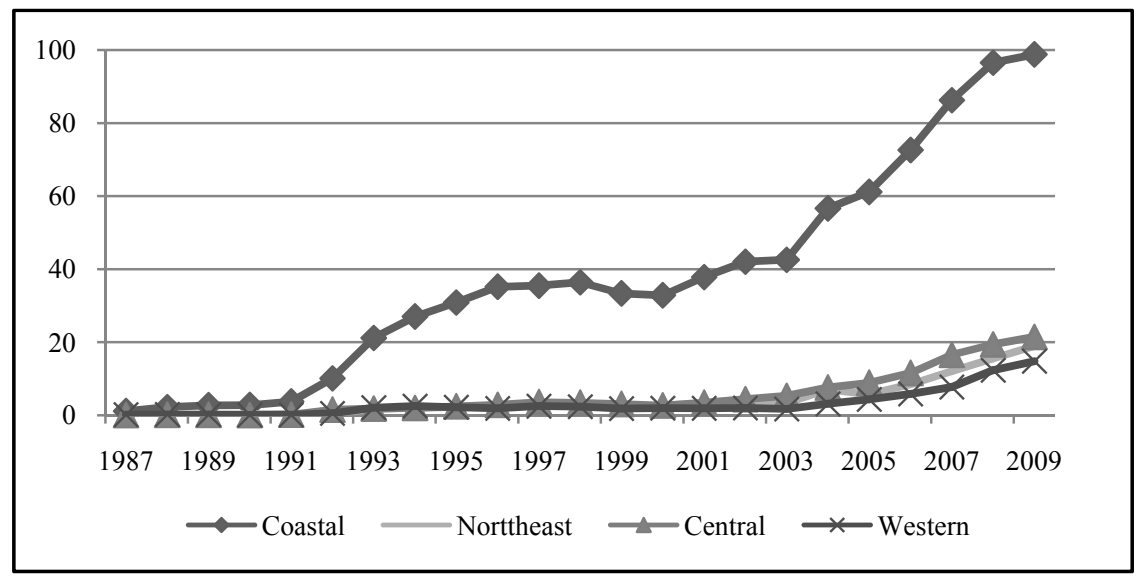

Figure 1. Regional distribution of FDI inflows, 1978-2009 (USD billion)

Source: Calculated from China Statistical Yearbook (Various issues).

FDI inflows recovered and surged faster after China joined the WTO in 2001. With deeper liberalisation and commitments to WTO, the annual growth rate of FDI was 18 per cent. This is equivalent to an increase of FDI inflows from USD 52.5 billion in 2002 to USD 154 billion in 2009. FDI inflows into the coastal region went up from USD 42 billion in 2001 to USD 98.8 billion in 2009 (Figure 1). For the western region, FDI inflow improved from USD 2 billion in 2002 to USD 14 billion in 2009, the northeast and central regions also experienced increased inflow from USD 4.0 billion to USD 19 billion and USD 4.4 to USD 21 billion, respectively. Although there was a diversified trend of regional distribution, the coastal region still held the dominant position in 2002-2009 by attracting some 71.5 per cent of cumulative FDI inflows. In contrast, the northeast, central and western regions only received 9.7 per cent, 12.2 per cent and 6.7 per cent, respectively.

Unfortunately, the uneven distribution of FDI inflows across the regions of China has not changed in the past three decades. Thus to help policy makers attract FDI into the less developed inland regions and to accelerate economic development of these regions, this paper examines and compares the regional determinants of FDI across China's four regions using multiple regression analysis. The determinants investigated are: market size, labour cost, labour quality, physical infrastructure, and telecommunication, degree of openness and government incentives to attract FDI. By comparing the results across four regions, it provides important implications for China's regional policy makers identify the kinds of industries which respond to specific drivers and identify regional social economic characteristics which are more attractive to particular FDI inflows.

The structure of this paper is as follows: section 2 provides literature review on location determinants of FDI inflows into China. Data and methodology are described in section 3. Section 4 discusses the empirical results, and section 5 concludes the paper.

\section{Literature Review on Location Determinants of FDI Inflows}

There are many theories to explain FDI activities, such as production life-cycle theory, ownership advantage theory and ownership, location and internalisation (OLI) paradigm. In this paper, the most relevant theory is the location theory, which explains why a multinational company (MNC) would choose to invest in a particular host country, or why choose to invest in a specific location within a particular host country. The location theory draws on policy, economy variables and cost of productions to explain why different locations are more or less attractive for FDI.

Based on location theory, the main location determinants of FDI are market size, labour costs, infrastructure development, government incentives, geographical location and the degree of openness. Sun et al. (2002) identified GDP, annual average wage per employee, total trade volume, transportation (railway density) and degree of industrialization as the more important determinants of FDI across 30 provinces of China. Better 
labour quality and infrastructure development also attracted more foreign investment. Furthermore, wages was found to positively affect FDI inflows. Similarly, Fung et al. (2006) examine the location determinants of FDI inflows into China from USA, Japan, Hong Kong, Taiwan and South Korea. They find that the GDP, length of highway and numbers of special zones in a region has highly significant effect on FDI location decisions, while the average was only negatively significant for Taiwanese investors. Boermans, Roelfsema and Zhang (2011) further show that foreign investors are attracted by provinces with low labour cost, large market size, and good transportation and communication facilities. Sethi, Judge and Sun (2011) developed a comprehensive intra-country framework of FDI inflows and when analysing FDI trends within China's 31 provinces find that infrastructure and preferential policies in other regions, rather than coastal region can help decongest FDI inflows distribution. Chen (2011) finds that regional economic development, measured by regional GDP, GDP per capita, total trade per regional GDP and infrastructure measured by density of railway, highway and water, and telecommunication all have positive effect on FDI inflows in the period of 1986 to 2005. In contrast labour cost, measured by the average wage adjusted by industrial productivity has a significant negative effect on FDI inflows.

\section{Determinant Factors on FDI}

Based on location theory and empirical studies previously discussed, we identify seven potentially important determinants of FDI inflows across four regions in China. As summarised in Table 1, they are market size, labour cost, labour quality, infrastructure development, and telecommunication, degree of openness and government incentives.

First of all, we hypothesized that market size have a positive impact on FDI inflows because it directly affects the expected revenue of the investment (Sun, et al., 2002). As China gradually opened its domestic market recently, FDI inflows became more domestic-market oriented, thus for foreign investors, the larger the market size of a particular region other things being constant, the more FDI flows to the region. In this paper, GDP per capita is used to measure the market size. (GDPPC, USD).

Labour cost, measured by the annual average wage paid to employee, is expected to have a negative effect on FDI. Higher wages, other things been equal, lowers profit, which will in turn reduce the attractiveness for foreign investment, especially for labour-intensive FDI. On the other hand, China attracts more foreign investment in technology-intensity industries, multinationals are willing to pay a premium to hire qualified workers. Hence, labour cost also reflects the endowment of skilled labour in a region, which should have a positive impact on FDI. (WAGE, USD dollar)

The labour quality is indicated by the number of graduates from university as a proportion of total regional population. Better labour quality reflects high level of capability to process and understand information and to cope with new task and procedures. Thus, this variable should have a positive impact on FDI. (GRAD, \%)

Physical infrastructure and telecommunication development are other major determinants of FDI inflows. The adequate infrastructure allows foreign investors not only decrease transportation cost but also improves effectiveness and efficiency of operation. Hence, multinationals should choose a location with better infrastructure. The level of physical infrastructure development of a particular region is measured by total length of highway and railway and inland waterway (HRWLENGTH, kilometres), and the telecommunication infrastructure development is measured by total length of cable. (TELECOM, kilometres)

The degree of openness is measured by the total foreign trade per total regional trade (FORETRADE, \%). The more open an economy the more linkage and activities with the rest of the world. Thus, the higher the degree of openness in a region, the more attractive to FDI inflows it will be, especially for the export-oriented FDI inflows. On the other hand, in some situation, the FDI inflows were caused by high trade barriers of a location, thus, multinationals choose FDI instead of trade to avoid high trading cost. In this case, the variable of degree of openness has the negative effects on FDI inflows.

The last factor to consider is the government incentives to attract FDI, which is proxied by the number of special zones in each region. Central government exclusively established different types of special zones in the coastal region until 1990s. In those special zones, foreign investors can enjoy preferential policies, such as exemption or reduction of profit taxes, land fees, import duties and priority obtaining infrastructure services. In turn, it gradually creates an unfair competition between coastal region and inland regions in terms of attract foreign investment. Thus, we believe the number of zones in each region (SZONES, unit) should have a positive relationship with FDI inflow. 
Table 1. Determinants of FDI Inflow

\begin{tabular}{lll}
\hline Independent Variable & Proxy Variable (Variable Name) & Expected Sign \\
\hline Market Size & GDP per capita (GDPPC) & + \\
Labour cost & Annual wage per employee (WAGE) & $+/-$ \\
Labour quality & Number of graduates from universities and colleges per total region regional population $(\mathrm{GRAD})$ & + \\
Physical infrastructure & Length of highway and railway and inland waterway (HRWLENGTH) \\
Telecommunication & Length of cable (TELECOM) \\
Degree of openness & Total trade from foreign enterprises per total regional trade (FORETRADE) \\
Government incentives & Total number of different types of zones(SZONE) \\
\hline
\end{tabular}

\section{Data and Analytical Framework}

Multiple regression analysis was carried out to examine the regional determinants of FDI inflows. Unlike other FDI studies in China, the data used in this paper are collected from various issues of 30 individual provincial yearbooks (Note 4). However, due to the unavailability of provincial variables in the early periods, our sample begins in 2001 and covers up t 2009. To our knowledge, the data used in this paper are the most up to date.

A problem associated with the data selection is the inconsistency between cumulative regional FDI inflows collected from the 30 provinces and the total FDI reported in the national statistical yearbook. Figure 2 shows the difference between the national statistic and the aggregated value as derived from the 30 provincial statistics on FDI inflows for the period 1987 to 2009. The solid line represents the aggregated value from the 30 provincial yearbooks, and the dashed line is the total FDI value from 'China Statistical Yearbook'. The graph further shows that the discrepancy has become higher in recent years. For instance, in 2009, the aggregated value came to USD 153.97 billion, whereas the figure reported by the national statistical yearbook was USD 90.03 billion only. This may be partly explained by regional governors exaggerating figures of FDI inflows in an attempt to attract foreign capital and promote economic growth. As this paper is focused on the regional distribution of realized FDI inflows, the data collected from provincial yearbook is more appropriate data to use. Since the GDP per capita and the annual wage are denominated in Chinese Yuan (RMB), we convert RMB to USD using yearly average USD/RMB exchange rate.

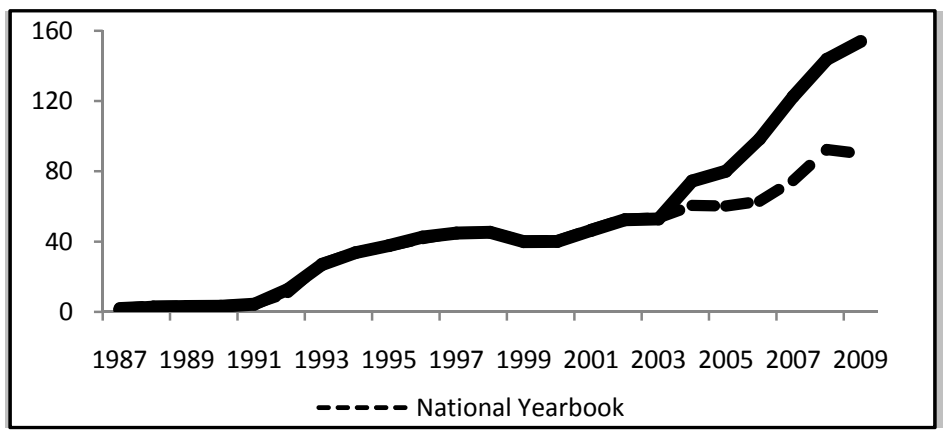

Figure 2. Comparison of Realized FDI inflow into China between National Statistical Yearbook and 30 Provincial Yearbook, 1987-2009 (USD billion)

Source: China Statistical Yearbook and 30 Provincial Statistical Yearbooks.

The empirical strategy was to establish a benchmark model for determinants of FDI inflows into coastal region and then apply the same model to the other three regions. All location determinants, except the number of special zones are lagged by one (1) period. This was due to two reasons; firstly, decisions to undertake FDI in a current year will not be realised in the sense that actual FDI flows does not eventuate until a year later, in other words, multinationals FDI activities in a given year are based on information gathered from the previous year. Secondly, as mentioned by Sun et al. (2002), the amount of FDI inflows and the independent variables may affect each other. For instance, better economic condition in a province attracts FDI inflows, in turn, FDI promote economic development in the region. In order to avoid the endogeneity problem, we are using lag variables. We also transformed GDPPC, WAGE, HRWLENGTH, TELECOM into natural logarithm. This will allow us to test whether FDI growth is determined by the growth rate of GDP and other factors. The regression model specified for this study is written as: 


$$
\begin{aligned}
\operatorname{lnFDI}_{i t}=\alpha_{i t}+ & \beta_{1} \ln \left(\text { GDPPC }_{i, t-1}\right)+\beta_{2} \ln \left(\text { WAGE }_{i, t-1}\right)+\beta_{3}\left(\text { GRAD }_{i, t-1}\right)+\beta_{4} \operatorname{In}\left(\text { HRWLENGTH }_{i, t-1}\right) \\
& +\beta_{5} \ln \left(\text { TELECOM }_{i, t-1}\right)+\beta_{6}\left(\text { FORETRADE }_{i, t-1}\right)+\beta_{7}\left(\text { SZONES }_{i, t}\right)+\varepsilon_{i t}
\end{aligned}
$$

where subscript $i$ refers to individual province and $t$ refers to year from 2001-2009. The variables used here are defined in Table 1.

\section{Empirical Results}

The descriptive statistics for all variables across the four regions are presented in tables $2 \mathrm{a}$ to $2 \mathrm{~d}$. There are ten (10) provinces in coastal region, three (3) provinces in northeast region and six (6) and eleven (1) provinces in central and western regions, respectively. Based on the mean value of FDI inflow to each region, the coastal region has the highest average inflow followed by the western region, northeast region and central region, which are USD 6604.1 million, USD 2902.5 million, UAS 1825.2 million and USD 544.21 million, respectively. However, the coastal region also has the highest standard deviation. This indicates that the FDI inflows into the 10 provinces in the coastal region are more varied compared to other regions. The coastal region also has the highest average GDP per capita, indicating that economic development is much faster in this region compared to the other three regions. GRAD represents the number of graduates from university per 10000 regional populations used here to indicate the labour quality. The results reveal that there are 3 university graduates per 10,000 populations while northeast, central and western region only has 1.21 .4 and 1 graduates, respectively. This also indicates that the coastal region has a better supply of highly educated labour force compared to the other three regions. The physical infrastructure and telecommunication are denoted by HRWLENGTH and TELECOM respectively. As expected, the total length of highway, railway and inland waterway and cable in western region and central region are much longer than coastal region as they represent a much larger land area. In terms of the percentage of foreign trade per total regional trade the coastal region accounts for 54 per cent of total trade from foreign investors, while only 39 per cent 26 per cent and 17 per cent are in the other three regions. Moreover, in the western region, the minimum percentage of foreign trade is recorded at only 1 per cent; this is much lower compared to that of coastal region (16 per cent). Furthermore, in terms of special zones the coastal region also surpasses the other three regions as it is the most opened region for foreign investment in China. The number of special zones in each region ranges from 3 to 31 .

Table 2a. Descriptive Statistics -Coastal region

\begin{tabular}{llllll}
\hline & Observations & Mean & Std. Dev. & Minimum & Maximum \\
\hline FDI & 90 & 660406.6 & 552133.2 & 42125 & 2532298 \\
GDPPC & 90 & 3285.7 & 2136.2 & 832.8 & 10814.7 \\
WAGE & 90 & 2611.6 & 1511.7 & 844.3 & 8144.5 \\
GRAD & 90 & 0.0030364 & 0.00224 & 0.000485 & 0.0089781 \\
HRWLENGTH & 90 & 68487.1 & 57771.8 & 6681.5 & 225333 \\
TELECOM & 90 & 13557.7 & 12209.7 & 333 & 45807 \\
TORETRADE & 90 & 0.54 & 0.19 & 0.16 & 0.82 \\
SZONES & 90 & 12.1 & 7.5 & 3 & 31 \\
\hline
\end{tabular}

Table 2b. Descriptive Statistics -Northeast region

\begin{tabular}{llllll}
\hline & Observations & Mean & Std. Dev. & Minimum & Maximum \\
\hline FDI & 27 & 290245.6 & 377224.8 & 19059 & 1544390 \\
GDPPC & 27 & 1907.3 & 910.8 & 827.1 & 4569.6 \\
WAGE & 27 & 1909.8 & 886.7 & 842.4 & 3992.6 \\
GRAD & 27 & 0.0025973 & 0.0012079 & 0.000924 & 0.0046886 \\
HRWLENGTH & 27 & 77666.0 & 33713.5 & 40477.4 & 161731 \\
TELECOM & 27 & 21239.7 & 9361.8 & 6162 & 40483 \\
TORETRADE & 27 & 0.39 & 0.21 & 0.06 & 0.65 \\
SZONES & 27 & 7.7 & 3.9 & 5 & 14 \\
\hline
\end{tabular}


Table 2c. Descriptive Statistics -Central region

\begin{tabular}{llllll}
\hline & Observations & Mean & Std. Dev. & Minimum & Maximum \\
\hline FDI & 54 & 182524.1 & 1133895.2 & 21164 & 479858 \\
GDPPC & 54 & 1293.9 & 651.6 & 586.0 & 3096.6 \\
WAGE & 54 & 2068.2 & 952.3 & 837.1 & 4916.6 \\
GRAD & 54 & 0.0020994 & 0.001473 & 0.000475 & 0.006161 \\
HRWLENGTH & 54 & 110098.4 & 53325.9 & 44827.6 & 245954 \\
TELECOM & 54 & 21083.4 & 6798.3 & 7019 & 35719 \\
TORETRADE & 54 & 0.26 & 0.11 & 0.10 & 0.65 \\
SZONES & 54 & 3.8 & 1.1 & 2 & 6 \\
\hline
\end{tabular}

Table 2d. Descriptive Statistics -Western region

\begin{tabular}{llllll}
\hline & Observations & Mean & Std. Dev. & Minimum & Maximum \\
\hline FDI & 99 & 54420.9 & 80491.6 & 1534 & 401643 \\
GDPPC & 99 & 1227.5 & 774.5 & 321.6 & 5077.4 \\
WAGE & 99 & 2119.7 & 1108.8 & 835.7 & 6807.7 \\
GRAD & 99 & 0.0015209 & 0.0010389 & 0.000366 & 0.005776 \\
HRWLENGTH & 99 & 84894.2 & 53981.2 & 11289.1 & 238208 \\
TELECOM & 99 & 21478.4 & 11456.5 & 2638 & 58611 \\
TORETRADE & 99 & 0.17 & 0.10 & 0.01 & 0.41 \\
SZONES & 99 & 3.9 & 2.0 & 1 & 7 \\
\hline
\end{tabular}

To summarize, the results show that in terms of economic development, labour quality and degree of openness, the coastal region is in a much superior position compared to the other three regions. However, the coastal region also has the highest labour cost (measured by average annual wage per employee) compared to other regions. In terms of physical and telecommunication infrastructure development, the inland regions have more development compared to the coastal region. This is partly due to the fact that the inland region has the largest land area and thus requires more infrastructure development. Overall, the regression results show a mixed picture of the regional determinants of FDI among the four (4) regions. The model has a poor explanatory power for western region, as the overall R-square is only 0.492 , and none of the location determinant variables is statistically significant. On the other hand, R-square of the northeast region and coastal region are both more than 0.90. Data shows that the western region has never been an attractive destination for foreign investment since China opened its door to trade. This result is further supported by the fact that the western region only receives 6 per cent of total utilised FDI.

Among the other three regions, there is no single common explanatory variable that has a significant effect on location determinants of FDI inflows. The determinants that are identified to be of significance are market size (GDPPC), labour cost (WAGE), labour quality (GRAD), physical infrastructure development (HRWLENGTH) and government incentives to attract FDI inflows represented by the different types of special zones (SZONES).

Table 3. Location Determinants of Regional Distribution of FDI Inflows across Four Regions, 2001-2009

\begin{tabular}{lllll}
\hline & Coastal (a) & Northeast (b) & Central (c) & Western (d) \\
\hline CONS & $5.20(0.000)^{* * *}$ & $21.38(0.007)^{* * * *}$ & $-6.28(0.138)$ & $-2.19(0.433)$ \\
GDPPC & $0.56(0.000)^{* * *}$ & $1.65(0.032)^{* *}$ & $0.71(0.204)$ & $0.81(0.105)$ \\
WAGE & $-0.25(0.016)^{* *}$ & $-2.70(0.002)^{* * *}$ & $-0.15(0.551)$ & $0.21(0.685)$ \\
GRAD & $110.18(0.010)^{* * *}$ & $981.14(0.002)^{* * *}$ & $-140.72(0.399)$ & $95.09(0.550)$ \\
HRWLENGTH & $0.05(0.608)$ & $-0.30(0.597)$ & $1.17(0.001)^{* * *}$ & $0.38(0.110)$ \\
TELECOM & $0.19(0.003)^{* * *}$ & $-0.16(0.672)$ & $-0.03(0.942)$ & $-0.00(0.991)$ \\
FORETRADE & $0.36(0.233)$ & $-1.67(0.169)$ & $2.54(0.054)^{*}$ & $0.19(0.847)$ \\
SZONES & $0.08(0.000)^{* * *}$ & $0.18(0.000)^{* * *}$ & $0.16(0.125)$ & $0.15(0.196)$ \\
\hline R-sq(overall) & 0.9057 & 0.9469 & 0.7237 & 0.492 \\
Wald chi2(7) & 0.0000 & 0.0000 & 0.0000 & 0.0000 \\
\hline
\end{tabular}

Note: () represents p-value, ${ }^{* * *}, * *, *$ denote statistical significance at $1 \%, 5 \%$ and $10 \%$ level, respectively. 
Table 3 reveals that there are different drivers of FDI inflows for each region. For the coastal region, all variables are significant other than physical structure and degree of openness as measured by HRWLEGTHB and FORETRADE respectively. In addition, the results show that a 1 per cent increase in GDP per capita leads to a 0.56 per cent and 1.65 per cent increase in FDI inflows into the coastal and the northeast regions, respectively. This indicates that the northeast region's domestic market is more attractive to foreign investors than the coastal region. This finding can partly be explained by the fact that a higher degree of competition among foreign investors exist in the coastal region as it has been opened to FDI for much longer compared to the newly opened and higher market potential northwest region.

Although the labour cost (WAGE) is found to have a negative effect on FDI inflows in coastal, northeast and central regions, it is only statistically significant for coastal and northeast regions. The results show that a 1 per cent increase in average annual wage paid to employee reduces FDI by 0.25 per cent flowing into the coastal region and 2.7 in the northeast region. In recent years, the labour cost in China increased significantly due to changes in minimum wage legislation (Note 5) and increased competition among firms in the regions. Higher labour costs results to higher production cost which has direct adverse effect on profits. Thus, the labour cost is found to be negatively correlated with FDI inflows in the sample period.

Due to the high speed of economic growth and spill-over effect from previous FDI inflows, the productivity and labour quality in the coastal and northeast regions has increased dramatically. The nature of FDI inflows into the coastal and northeast are described as more high-technology and capital-intensive. The traditional low-technology, labour-intensive FDI is shifting into the inland regions. We therefore hypothesised that the labour quality is a crucial determinant factor for the FDI into the northeast and coastal region. Our regression results support this. We found that the labour quality represented by the variable GRAD has the expected sign and are significant in these regions. In contrast, the bulk of FDI inflows into central and western region have been from Asian newly-industrialized economies and the focused is on the production of labour-intensive products thus GRAD was found not to be significant in these regions. These same regions, however, requires more physical infrastructure rather than telecommunication to conduct their FDI activities. Thus, the physical infrastructure variable (HRWLENGTH) is found to be an important variable to explain FDI inflows into central region.

The coefficients of the variable representing government incentives to attract FDI inflows (SZONES) is positive and statistically significant at 1 per cent level for coastal and northeast region (Table 3, column a \& b). This indicates that the FDI inflows into these two regions are influenced by the preference policies implemented in the special zones. However, this same variable is found to be statistically insignificant but with the right expected sign for both the central and western regions. The results setting up special zones and implementing preferential treatments for foreign investors cannot compensate the underdeveloped economic condition and human capital.

To test the robustness of the four regional models we carried out various diagnostic tests. The variance inflation factor (VIF) tests results show that the models do not suffer from multicollinearity and the Durbin Watson tests find no problem of autocorrelation.

\section{Conclusions}

Regional disparity of inward FDI inflows has important policy implications as there is a link between FDI inflows and China's economic growth. Inland regions consider FDI inflows as one of the most important source of economic development. Thus, in order to provide useful information to regional policy makers on how to attract FDI into their areas, a location theory is used in this study to empirically identify the factors that significantly determine FDI inflows across four regions in China for the period 2001-2009. A panel data analysis was used to ascertain which of the determinants are the drivers for each region.

The empirical results clearly show that the uneven regional distribution of FDI inflows into China is caused by the differences in provincial characteristics and location factors of each individual region. We found that the location determinants in coastal region and northeast are quite similar. The results further reveal that market size, labour quality, and government incentives to attract FDI are significantly positively affecting the FDI inflows, while the high labour cost reduces the attractiveness of a region. The physical infrastructure in central region is a crucial factor to attract FDI, as huge amounts of low-technology, labour-intensive FDI from newly-industrialised economies are concentrated in the central region.

More importantly, the results here have significant implications for policy makers. Firstly, in order to help less developed inland regions to attract FDI, there is a need to upgrade human capital and further development of the infrastructure. Secondly, the preferential policies should be industrial based, rather than location based. In other 
words, government policy to encourage high-tech FDI inflow into well developed coastal region, while attracting low-tech and labour- intensive FDI inflows into the less developed inland regions need to be put into action. Thirdly, in order for China to attract FDI, the government needs to encourage the transfer of skilled labour and technology to inland regions, for these regions to have maximum benefit from FDI.

\section{References}

Boermans, M. A., Todlfsema, H., \& Zhang, Y. (2011). Regional determinants of FDI in China: a factor-based approach. Journal of Chinese economic and business studies, 9(1), 23-42. http://dx.doi.org/10.1080/14765284.2011.542884

Chen, C. (2011). Provincial characteristics and the FDI location decision within China, Foreign direct investment in China. Location determinants, investor differences, and economic impacts (pp. 132-51). Elgar Publishing Limited, UK.

Fung, K. C., Garcia-Herrero, A., Lizaka, H., \& Siu, A. (2006). Hard of soft? Institutional reforms and infrastructure spending as determinants of foreign direct investment in China. Japanese economic review, 56(4), 408-16. http://dx.doi.org/10.1111/j.1468-5876.2005.00342.x

Kang, S. J., \& Lee, H. S. (2007). The Determinants of Location Choice of South Korean FDI in China. Japan and the world economy, 19(4), 441-60. http://dx.doi.org/10.1016/j.japwor.2006.06.004

Sethi, D., Judge, W., \& Sun, Q. (2011). FDI distribution within China: An integrative conceptual framework for analysing intra-country FDI variations. Asia pacific journal of management, 28(2), 325-52. http://dx.doi.org/10.1007/s10490-009-9144-5

Sun, Q., Tong, W., \& Yu, Q. (2002). Determinants of foreign direct investment across China. Journal of international money and finance, 21(1), 79-113. http://dx.doi.org/10.1016/S0261-5606(01)00032-8

\section{Notes}

Note 1. The classification was adopted in the Eleventh Five-year Plan (2006-2010).

Note 2. The word 'province' means any one of the provincial-level administrative units. Includes province, centrally administered municipality and autonomous. Tibet is excluded in this study.

Note 3. The sub-period was followed by Chen (2011).

Note 4. According to the National Statistical Yearbook, the provincial distribution of FDI inflows only provided until 2004, thereafter, there is no data available from the national statistical yearbook.

Note 5. The minimum wage level across China was introduced by China's Ministry of Human Resources and Social Security. 